\title{
PENERAPAN MODEL PEMBELAJARAN ARCS DAN ACTIVE LEARNING TERHADAP HASIL BELAJAR MATEMATIKA DITINJAU DARI MOTIVASI BELAJAR SISWA SMK
}

\author{
Yudhi Hanggara*1 ${ }^{1}$, Irwan Juniman Zendato ${ }^{2}$ \\ ${ }^{1,2}$ Program Studi Pendidikan Matematika Fakultas Keguruan dan Ilmu Pendidikan \\ Universitas Riau Kepulauan, Batam, Kepulauan Riau \\ email: ${ }^{* 1}$ yudhi@fkip.unrika.ac.id
}

\begin{abstract}
Abstrak.Penelitian ini bertujuan untuk mengetahui: (1) Perbedaan hasil belajar matematika siswa yang diberikan perlakuan model pembelajaran ARCS dengan model pembelajaran Active Learning. (2) Perbedaan hasil belajar matematika siswa yang memiliki motivasi belajar tinggi, sedang dan rendah. (3) Interaksi antara model pembelajaran (ARCS dan Active Learning) dengan motivasi belajar siswa. Jenis penelitian ini adalah penelitian quasi eksperimen dengan desain faktorial $2 \times 3$. Populasi pada penelitian ini adalah seluruh siswa kelas X SMKN 2 Batam tahun pelajaran 2016/2017. Sampel diperoleh kelas X Akutansi-2 sebagai kelas eksperimen-1 dan kelas X Akutansi-4 sebagai kelas eksperimen-2. Instrumen pada penelitian ini adalah tes dan angket Uji prasyarat meliputi uji normalitas dengan metode Lilliefors dan uji Homogenitas dengan metode Bartlett. Pengujian hipotesis pada penelitian ini menggunakan analisis variansi dua jalan dengan sel tak sama. Hasil penelitian menyimpulkan bahwa: (1) tidak terdapat perbedaan hasil belajar matematika antara siswa yang diberikan perlakuan model pembelajaran ARCS dengan model pembelajaran Active Learning. (2) terdapat perbedaan hasil belajar metematika antara siswa yang memiliki motivasi belajar tinggi dan rendah. (3) tidak terdapat interaksi antara model pembelajaran dengan motivasi belajar siswa.
\end{abstract}

Kata Kunci: ARCS, Active Learning, motivasi belajar, hasil belajar matematika

\begin{abstract}
This study aims to determine: (1) The difference in learning outcomes of student who study mathematics using ARCS learning model with Active learning model. (2) The difference in mathematics learning outcomes in student who have hight, medium and low motivation. (3) Interaction between learning model (ARCS and Active Learning) with student learning motivation. This research is quasi-experimental study with factorial design $2 \times 3$. The population in this research is all of students class X SMKN 2 Batam with academic year 2016/2017. The Sample in this research from class $X$ accountant- 2 is used as sampling for $1^{\text {st }}$ experiment and class $X$ accountant 4 for $2^{\text {nd }}$ experiment. Instrument of research are mathematics achievement test and questionnaire student motivation. The test requirement is normality test using Lilliefors method and homogeneity test using Bartlett method. Hypothesis testing in this study uses two-way analisis of variance with defferent cells. Conclusion in this study: (1) there is no difference between student math result between ARCS learning model with Active learning model. (2) there is difference between result of student math between learning high motivation with low motivation. (3) there is no interaction between the learning model with student motivation.
\end{abstract}

Keywords: ARCS, Active Learning, Motivation learning, Study of Math

\section{Pendahuluan}

Proses pembelajaran disetiap sekolah tentunya mengacu pada materi pembelajaran. Pencapaian materi pembelajaran oleh siswa di sekolah dapat dilihat dari hasil belajar siswa atas pencapaian pada kompetensi dasar dari meteri pembelajaran. Untuk mencapai hasil belajar yang diharapkan, banyak hambatan yang akan dihadapi siswa dan guru. Prediksi hasil pembelajaran yang rendah dapat diakibatkan oleh masalah-masalah dalam pembelajaran berupa: terbatasnya sarana dan prasarana belajar, penyampaian materi pembelajaran yang tidak dapat dimengerti oleh siswa secara cepat dan tepat karena model pembelajaran dan 
metode yang dilakukan tidak cocok dengan materi pembelajaran atau terlalu rumit materi pembelajaran yang menimbulkan tingkat kemandirian dan motivasi belajar siswa menurun serta ketekunan, keaktifan dan kerajinan siswa menjadi rendah.

Berdasarkan observasi yang dilakukan peneliti di SMK Negeri 2 Batam pada siswa kelas X, motivasi belajar siswa masih rendah. Hal ini dapat di dilihat dari keseharian siswa yang motivasi mengerjakan Pekerjaan Rumah (PR) semakin menurun. Model pembelajaran yang digunakan saat proses pembelajaran di kelas adalah model pembelajaran berbasis kurikulum 2013. Adapun model pembelajaran yang diterapkan tidak bervariasi, sehingga dapat menyebabkan suasana pembelajaran menjadi membosankan, menciptakan proses pembelajaran yang kurang menarik dan bermakna bagi siswa. Keaktifan siswa dalam belajar matematika juga dapat di kategorikan rendah, hal ini dipengaruhi oleh faktor-faktor seperti rendahnya daya saing belajar dan materi pembelajaran yang baru mereka hadapi, sehingga siswa mengasumsikan materi pembelajaran tersebut menjadi sulit. Banyaknya jumlah siswa di dalam kelas yang tidak didukung oleh sarana dan prasarana yang cukup juga dapat menyebabkan suasana pembelajaran tidak nyaman dan aktifitas belajar menjadi tidak optimal. Hal ini tentunya menjadi kendala terhadap guru. Misalkan kesulitan yang akan dihadapi guru adalah saat mengevaluasi kemampuan siswa dalam menguasai materi pembelajaran. Motivasi belajar siswa yang kurang tentu berdampak pada hasil pembelajaran siswa. Hasil belajar matematika yang diperoleh siswakelas X di SMK Negeri 2 Batam masih dikategorikan rendah hal ini tergambar seperti pada tabel 1 dibawah ini:

Tabel 1. Presentase Ketercapaian KKM UAS Matematika Kelas X SMKN 2 Batam (KKM = 75)

\begin{tabular}{cccccc}
\hline & \multirow{2}{*}{ KELAS } & TOTAL & \multicolumn{2}{c}{ Tuntas $(\geq 75)$} & \multicolumn{2}{c}{ Tidak Tuntas $(<75)$} \\
\cline { 3 - 6 } & SISWA & $\begin{array}{c}\text { Jumlah } \\
\text { Siswa }\end{array}$ & Persentase & $\begin{array}{c}\text { Jumlah } \\
\text { Siswa }\end{array}$ & Persentase \\
\hline X UPW & 56 & 5 & $8,93 \%$ & 51 & $91,07 \%$ \\
X PH & 58 & 6 & $10,34 \%$ & 52 & $89,66 \%$ \\
X JB 1 & 58 & 13 & $22,41 \%$ & 45 & $77,59 \%$ \\
X JB 2 & 58 & 9 & $15,52 \%$ & 49 & $84,48 \%$ \\
X Akutansi 1 & 56 & 11 & $19,64 \%$ & 45 & $80,36 \%$ \\
X Akutansi 2 & 52 & 19 & $36,54 \%$ & 33 & $63,46 \%$ \\
X Akutansi 3 & 57 & 8 & $14,04 \%$ & 49 & $85,96 \%$ \\
X Akutansi 4 & 57 & 29 & $50,88 \%$ & 28 & $49,12 \%$ \\
X Akutansi 5 & 57 & 7 & $12,28 \%$ & 50 & $87,72 \%$ \\
\hline
\end{tabular}

Sumber: Data Guru Hasil Belajar Matematika SMKN 2 BataM (21 November 2016 Nilai UAS Ganjil Sebelum Remedial)

Berdasarkan Tabel 1, hasil belajar yang diperoleh siswa kurang memuaskan. Beberapa metode pembelajaran telah dilakukan, seperti penggunaan media presentasi, modul belajar, dan pemberian tugas individu ternyata belum menunjukkan hasil yang memuaskan. Permasalahan-permasalahan dalam proses pembelajaran tersebut perlu dicarikan solusinya agar tujuan dari pembelajaran dapat tercapai optimal. Salah satu caranya adalah dengan 
menemukan model atau metode pembelajaran yang efektif, yang dapat memperbaiki daya tangkap siswa dan diharapkan dapat menumbuhkan semangat belajar, keaktifan siswa serta memacu peningkatan hasil belajar yang diinginkan.

Dari permasalahan di atas, peneliti hendak menerapkan suatu model pembelajaran yang diharapkan mampu meningkatkan hasil belajar matematika siswa. Model pembelajaran tersebut adalah ARCS dan Active learning. Selain menggunakan dua model pembelajaran untuk membandingkan hasil belajar matematika siswa, peneliti juga meninjau motivasi siswa yang memberikan dampak terhadap hasil belajar matematika.

Menurut Direktorat Jenderal Pendidikan Tinggi program PEKERTI (Peningkatan Keterampilan Dasar Teknik Instruksional) dalam Ginting (2010) mengemukakan sebuah model pengelolaan motivasi belajar yang dikenal dengan istilah ARCS. ARCS merupakan singkatan dari Attention (perhatian), relevance (kesesuaian), confidence (kepercayaan diri), dan Sastisfaction (kepuasan). Menurut program PEKERTI tersebut, keempat faktor ARCS ini dapat memberikan pengaruh untuk membangkitkan motivasi belajar siswa. Model pembelajaran ARCS di kelompokan menjadi empat komponen, yaitu:

a. Attention (perhatian/membangkitkan dan mempertahankan perhatian siswa selama pembelajaran).

Perhatian adalah bentuk pengarahan untuk dapat berkonsultasi/ pemusatan pikiran dalam menghadapi siswa pada peristiwa proses belajar mengajar di kelas. Selama pembelajaran berlangsung, motivasi dan perhatian siswa harus dibangkitkan dan dipertahankan. Guru harus memperhatikan berbagai bentuk strategi untuk membangkitkan perhatian siswa selama pembelajaran.

b. Relevance (mengaitkan pembelajaran dengan kebutuhan siswa).

Menurut Andari dan Lusiana dalam Farida (2016), siswa akan terdorong mempelajari sesuatu kalau apa yang dipelajari ada relevansinya dengan kehidupan mereka, dan memiliki tujuan yang jelas. Untuk mengaitkan isi pembelajaran dengan kebutuhan siswa, guru perlu: (a) menumbuhkan keakraban dan kebiasaan yang baik, (b) menyajikan isi pembelajaran yang berorientasi pada tujuan, (c) menggunakan strategi yang sesuai.

c. Confidence (menumbuhkan rasa yakin pada diri siswa)

Sikap percaya diri, yakni akan hasil perlu ditanamkan kepada siswa untuk mendorong mereka berusaha dengan maksimal mencapai hasil yang optimal. Menurut Wina dalam Farida (2016), untuk menumbuhkan keyakinan pada diri siswa terdapat tiga cara yaitu: 1). Menyajikan prasayat belajar. 2). Memberikan kesempatan untuk sukses. 3). Memberikan kesempatan melakukan kontrol pribadi.

d. Satisfaction (membangkitkan rasa puas siswa terhadap pembelajaran)

Siswa dikatakan puas apabila berhasil mengerjakan atau mencapai sesuatu kemudian merasa bangga atas keberhasilan tersebut. Keberhasilan dan kebanggaan itu menjadi penguat bagi siswa tersebut untuk mencapai keberhasilan berikutnya.

Menurut Awoniyi dalam Zulfira (2014) model pembelajaran ARCS mempunyai kelebihan yaitu:

1. Memberikan petunjuk, aktif dan arahan tentang apa yang harus dilakukan oleh siswa.

2. Cara penyajian materi dengan modal ARCS ini bukan hanya dengan teori yang 
penerapannya kurang menarik.

3. Motivasi yang diperkuat oleh rancangan bentuk pembelajaran berpusat pada siswa.

4. Penerapan model ARCS meningkatkan motivasi untuk mengulang kembali materi.

5. Penilaian menyeluruh terhadap kemampuan-kemampuan yang lebih dari karakteristik siswa-siswa agar strategi pembelajaran lebih efektif.

Sedangkan model pembelajaran Active learning adalah suatu proses pembelajaran dengan maksud untuk memberdayakan peserta didik agar belajar dengan menggunakan berbagai cara/strategi secara aktif. Active Learning memiliki bebarapa macam tipe, yaitu: (a) Resume Kelompok, (b) Debat Aktif, (c) Turnamen Belajar, (d) Kuis Tim, (e) Pertukaran Kelompok, (f) Jurnal Belajar, (g) Bergilir Peran, (h) Lempar Bola, (i) Bowling Kampus, (j) Mozaik Penilaian, dan lain-lain (Silberman, 2013)

Pembelajaran Aktive Learning memiliki tiga tujuan yaitu: pembentukan tim, penilaian sederhana, dan keterlibatan belajar langsung. Apabila ketiga tujuan ini dapat dicapai maka dapat meningkatkan kemampuan siswa untuk ambil bagian dalam kegiatan belajar aktif. Kelebihan model pembelajaran Active Learning dengan tipe turnamen menurut Silberman (2013) adalah: 1). Membuat siswa aktif. 2). Membantu siswa memperoleh pengetahuan, ketrampilan dan sikap belajar yang aktif. 3).Membuat pelajaran tidak mudah dilupakan.

Selain model pembelajaran variabel bebas dalam penelitian ini adalah motivasi belajar. Ormrod dalam Widoyoko (2012) mengatakan bahwa, "Motivation has several effect on students' learning and behavior: it directs behavior toward particular goal. It leads to increased effort and energy. It increased initiation of, and persistence in activities. It enhances cognitive processing. It lead to improved performance". Hal ini menerangkan bahwa motivasi memberikan efek pada belajar dan perilaku siswa yang mana mengarahkan perilaku ke arah tujuan tertentu. Serta memberikan peningkatan usaha dan energi dalam meningkat inisiasi dan ketekunan. Motivasi juga meningkatkan cara berpikir dan meningkatkan kinerja untuk prestasi yang lebih baik. Hal ini juga di kemukakan oleh Direktorat Tenaga Kependidikan Jenderal Peningkatan Mutu Pendidikan dan Tenaga Kependidikan Departemen Pendidikan Nasional (2008) bahwa motivasi sangat penting dalam belajar karena motivasi dapat mendorong siswa mempresepsikan informasi dalam bahan ajar. Sebagus apa pun rancangan bahan ajar, jika siswa tidak termotivasi maka tidak akan terjadi peristiwa belajar karena siswa tidak akan mempresepsikan informasi dari bahan ajar tersebut.

Menurut Hamalik (2014: 108) fungsi motivasi adalah 1). Mendorong timbulnya tingkah laku atau perbuatan. Tanpa motivasi tidak akan timbul suatu perbuatan misalnya belajar. 2). Motivasi berfungsi sebagai pengarah, artinya mengarahkan perbuatan untuk mencapai tujuan yang diinginkan. 3). Motivasi berfungsi sebagai penggerak, artinya menggerakkan tingkah laku seseorang. Besar kecilnya motivasi akan menentukan capat lambatnya suatu pekerjaan.

\section{Metodologi Penelitian}

Jenis penelitian ini adalah penelitian eksperimental semu dengan desain $2 \times 3$. Variabel bebasnya adalah model pembelajaran dan motivasi belajar, serta variabel terikatnya adalah hasil belajar matematika siswa.

Populasi penelitian ini adalah seluruh siswa kelas X SMK N 2 Batam. Pengambilan sampel dilakukan dengan teknik cluster random sampling. Sampel dalam penelitian ini 


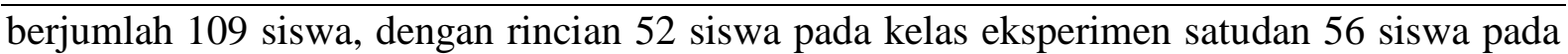
kelas eksperimen dua

Teknik pengumpulan data yang digunakan dalam penelitian ini adalah dengan menggunakan tes, angket dan dokumentasi. Tes digunakan untuk mengetahui hasil belajar siswa setelah mengikuti pembelajaran, angket digunakan untuk mengetahui motivasi belajar siswa, dan dokumentasi digunakan untuk uji keseimbangan rata-rata. Instrumen yang digunakan dalam penelitan ini berupa tes uraian yang digunakan untuk mengukur hasil belajar siswa dan angket untuk memperoleh data kategori motivasi belajar siswa.

\section{Hasil Penelitian dan Pembahasan}

Kemampuan awal pada penelitian ini diambil dari hasil ujian sekolah semester ganjil tahun 2016 kemudian data itu diuji normalitas, uji homogenitas dan uji keseimbangan antara rerata kelas dengan model pembelajaran ARCS dan model pembelajaran Active Learning.

\section{Uji Normalitas}

Uji normalitas dengan menggunakan metode Liliefors, diperoleh hasil sebagai berikut:

Tabel 2. Rangkuman Hasil Uji Normalitas Kemampuan Awal

\begin{tabular}{lccccc}
\hline No. & Kelompok & $\mathbf{L}_{\text {obs }}$ & $\mathbf{L}_{\text {tab }}$ & Keputusan & Ket. \\
\hline 1 & ARCS & 0,1092 & 0,1229 & Diterima & Normal \\
2 & Active Learning & 0,0731 & 0,1184 & Diterima & Normal \\
\hline
\end{tabular}

Karena $\mathrm{H}_{0}$ diterima maka dapat disimpulkan bahwa kedua sampel tersebut berasal dari populasi yang berdistribusi normal.

2. Uji Homogenitas

Uji homogenitas menggunakan uji Bartlett, diperoleh hasil sebagai berikut

Tabel 3. Rangkuman Hasil Uji Homogenitas Kemampuan Awal

\begin{tabular}{|c|c|c|c|c|c|}
\hline No & Variabel & $\chi_{\text {hitung }}^{2}$ & $\chi_{\text {tabel }}^{2}$ & Keputusan uji & Keterangan \\
\hline 1 & ARCS dan Active Learning & 0,109 & & $\mathrm{H}_{0}$ diterima & Homogen \\
\hline
\end{tabular}

Karena $\mathrm{H}_{0}$ diterima maka dapat disimpulkan bahwa varians dari kelompok sampel homogen (sama).

\section{Uji Keseimbangan}

Uji keseimbangan dilakukan pada nilai ujian semester ganjil tahun 2016 untuk kelas eksperimen dengan model ARCS, dan Active Learning. Uji keseimbangan menggunakan analisis variansi satu jalan dengan sel tak sama. Hasil perhitungan diperoleh $\mathrm{F}_{\mathrm{obs}}=$ 0,213sedangkan $F_{\text {tabel }}=3,931$ sehingga $F_{\text {obs }}<F_{\text {tabel }}$. Jadi kedua kelompok berasal dari populasi dengan kemampuan awal sama.

\section{Uji Prasyarat}

Uji prasyarat dalam penelitian ini adalah uji normalitas dan uji homogenitas.Uji normalitas untuk mengetahui bahwa sampel berasal dari populasi yang berdistribusi normal, uji normalitas menggunakan uji Lilliefors.Sedangkan uji homogenitas untuk mengetahui 
apakah variansi-variansi berasal dari populasi yang homogen, uji homogenitas menggunakan uji Bartlett.

1. Uji Normalitas

Uji normalitas hasil belajar matematika siswa kelas X SMK N 2 Batam meliputi uji untuk kelompok siswa dengan:

a. model pembelajaran ARCS

b. model pembelajaran Active Learning (AL)

c. motivasi belajar tinggi

d. motivasi belajar sedang

e. motivasi belajar rendah.

Tabel 4. Rangkuman Hasil Uji Normalitas Data Penelitian

\begin{tabular}{clccccl}
\hline No. & Kelompok & $\mathbf{N}$ & $\mathbf{L}_{\text {obs }}$ & $\mathbf{L}_{\text {tab }}$ & Keputusan & Ket. \\
\hline 1 & ARCS & 56 & 0,1008 & 0,1184 & Ho diterima & Normal \\
2 & AL & 52 & 0,1183 & 0,1229 & Ho diterima & Normal \\
3 & M. Tinggi & 28 & 0,1094 & 0,1641 & Ho diterima & Normal \\
4 & M. Sedang & 54 & 0,0931 & 0,1206 & Ho diterima & Normal \\
5 & M. Rendah & 26 & 0,0865 & 0,1699 & Ho diterima & Normal \\
\hline
\end{tabular}

2. Uji Homogenitas

a. kelompok siswa dengan model pembelajaran ARCS dan Active Learning.

b. kelompok siswa dengan motivasi belajar tinggi, sedang dan rendah.

Tabel 5. Rangkuman Hasil Uji Homogenitas

\begin{tabular}{llcccl}
\hline No. & Kelompok & $\chi_{\text {obs }}^{\mathbf{2}}$ & $\boldsymbol{\chi}_{\boldsymbol{t a b}}^{\mathbf{2}}$ & Keputusan & Ket. \\
\hline 1 & Model Pembelajaran & 0,0039 & 3,841 & Ho diterima & Homogen \\
2 & Motivasi Belajar & 1,1607 & 5,991 & Ho diterima & Homogen \\
\hline
\end{tabular}

\section{Uji Anava}

Hasil perhitungan uji hipotesis dengan analisis variansi dua jalan $2 \times 3$ dengan sel tak sama dengan taraf signifikan $\alpha=0,05$ disajikan pada tabel berikut :

Tabel 6. Rangkuman Analisis Variansi Dua Jalan Dengan Sel Tak Sama

\begin{tabular}{lcccccc}
\hline \multicolumn{1}{c}{ Sumber } & JK & df & RK & $\mathbf{F}_{\text {obs }}$ & $\mathbf{F}_{\text {tab }}$ & $\begin{array}{c}\text { Keputusan } \\
\text { Uji }\end{array}$ \\
\hline Model Pembelajaran (A) & 2,85 & 1 & 2,85 & 0,01 & 3,93 & Ho diterima \\
Motivasi Belajar (B) & 2910,21 & 2 & 1455,10 & 4,74 & 3,09 & Ho ditolak \\
Interaksi (AB) & 14,23 & 2 & 7,12 & 0,32 & 3,09 & Ho diterima \\
Galat (G) & 29261,76 & 102 & 286,88 & - & - & - \\
Total & 32189,04 & 107 & - & - & & \\
\hline
\end{tabular}


Berdasarkan dari hasil perhitungan yang disajikan pada tabel 6 di atas tampak bahwa

a. Pada sumber A (model pembelajaran) diperoleh nilai statistik uji $F_{a}=0,01$ dan $F_{t a b}=$ 3,93. Ternyata $F_{a}<F_{\text {tab }}$, hal ini berarti $F_{a} \notin D K$. Dengan demikian $H_{0 A}$ diterima. Hal ini menunjukkan bahwa dengan taraf signifikan 5\% tidak terdapat perbedaan antara model pembelajaran ARCS dan Active Learning terhadap hasil belajar matematika siswa.

b. Pada sumber B (motivasi belajar matematika siswa), diperoleh nilai statistik uji $F_{b}=4,74$ dan $\mathrm{F}_{\mathrm{tab}}=3,09$. Ternyata $\mathrm{F}_{\mathrm{b}}>\mathrm{F}_{\mathrm{tab}}$, hal ini berarti $\mathrm{F}_{\mathrm{b}} \in \mathrm{DK}$. Dengan demikian $\mathrm{H}_{0 \mathrm{~B}}$ ditolak. Hal ini menunjukkan bahwa dengan taraf signifikan 5\% terdapat perbedaan antara motivasi belajar tinggi, motivasi belajar sedang dan motivasi belajar rendah terhadap hasil belajar matematika siswa.

c. Pada sumber interaksi AB (model pembelajaran dan motivasi belajar matematika siswa) diperoleh nilai statistik uji $F_{a b}=0,32$ dan $F_{t a b}=3,09$. Ternyata $F_{a b}<F_{t a b}$, hal ini berarti $\mathrm{F}_{\mathrm{ab}} \notin \mathrm{DK}$. Dengan demikian $\mathrm{H}_{0 \mathrm{AB}}$ diterima. Hal ini menunjukkan bahwa dengan taraf signifikan 5\% tidak terdapat interaksi antara model pembelajaran dan motivasi belajar siswa tarhadap hasil belajar matematika siswa.

\section{Uji Lanjut Pasca Anava}

Uji lanjut pasca anava bertujuan untuk melakukan pelacakan terhadap perbedaan rataan dari setiap baris, kolom dan antar sel. Berikut ini rangkuman hasil uji hipotesis pada tabel7 di bawah.

Tabel 7. Rangkuman Rataan Antar Sel dan Rerata Marginal

\begin{tabular}{|c|c|c|c|c|c|}
\hline \multicolumn{2}{|c|}{$\begin{array}{l}\text { Faktor B } \\
\end{array}$} & \multicolumn{3}{|c|}{ Motivasi Belajar (B) } & \multirow{2}{*}{$\begin{array}{l}\text { Rerata } \\
\text { Marginal }\end{array}$} \\
\hline Faktor A & & $\begin{array}{l}\text { Tinggi } \\
\left(\mathbf{B}_{1}\right)\end{array}$ & $\begin{array}{l}\text { Sedang } \\
\left(\mathbf{B}_{2}\right)\end{array}$ & $\begin{array}{l}\text { Rendah } \\
\left(\mathbf{B}_{\mathbf{3}}\right)\end{array}$ & \\
\hline \multirow{2}{*}{$\begin{array}{l}\text { Model } \\
\text { Pembelajaran } \\
\text { (A) }\end{array}$} & $\begin{array}{l}\text { ARCS } \\
\left(\mathbf{A}_{1}\right)\end{array}$ & 81,77 & 73,12 & 68,90 & 74,77 \\
\hline & $\begin{array}{l}\text { Active } \\
\text { Learning } \\
\left(\mathbf{A}_{2}\right)\end{array}$ & 82,27 & 74,33 & 68,31 & 74,38 \\
\hline \multicolumn{2}{|c|}{ Rerata Marginal } & 82,02 & 73,73 & 68,61 & \\
\hline
\end{tabular}

Uji lanjut pasca anava yang digunakan adalah metode uji Scheffe. Berdasarkan hasil uji hipotesis diperoleh $\mathrm{H}_{\mathrm{OB}}$ ditolak, maka perlu dilakukan uji komparasi ganda antar kolom. Sedangkan untuk $\mathrm{H}_{0 \mathrm{~A}}$ dan $\mathrm{H}_{0 \mathrm{AB}}$ diterima maka untuk uji komparasi antara baris dan antar sel tidak perlu dilakukan. Berikut ini hasil uji komparasi rerata antar kolom pada tabel 8 .

Tabel 8. Rangkuman Komparasi Antar Kolom

\begin{tabular}{cccc}
\hline Komparasi & $\mathbf{F}_{\text {obs }}$ & $\mathbf{F}_{\text {tab }}$ & Keputusan Uji \\
\hline $\mathrm{H}_{0}: \mu_{1}=\mu_{2}$ & 4,42 & 6,17 & $\mathrm{H}_{0}$ diterima \\
$\mathrm{H}_{0}: \mu_{1}=\mu_{3}$ & 8,45 & 6,17 & $\mathrm{H}_{0}$ ditolak \\
$\mathrm{H}_{0}: \mu_{2}=\mu_{3}$ & 1,60 & 6,17 & $\mathrm{H}_{0}$ diterima \\
\hline
\end{tabular}


Berdasarkan hasil uji komparasi rataan antar kolom pada masing masing motivasi belajar matematika siswa, dengan taraf signifikan 5\% diperoleh bahwa:

1. $\mathrm{H}_{0}: \mu_{1}=\mu_{2}$ diterima.

Rerata marginal untuk hasil belajar matematika pada siswa yang memiliki motivasi tinggi sebesar 80,02 sedangkan hasil belajar matematika pada siswa yang memiliki motivasi sedang sebesar 73,73. Secara bilangan, kedua rerata marginal berbeda. Namun, berdasarkan hasil komparasi dengan metode Scheffe diperoleh bahwa tidak terdapat perbedaan hasil belajar antara siswa yang memiliki motivasi belajar metematika tinggi dengan siswa yang memiliki motivasi belajar matematika sedang.

2. $\mathrm{H}_{0}: \mu_{1}=\mu_{3}$ ditolak.

Hal ini berarti terdapat perbedaan hasil belajar antara siswa yang memiliki motivasi belajar metematika tinggi dengan siswa yang memiliki motivasi belajar matematika rendah. Berdasarkan tabel 15,rerata marginal hasil belajar matematika siswa yang memiliki motivasi tinggi yakni 82,02 sedangkan rerata marginal hasil belajar matematika siswa yang memiliki motivasi rendah sebesar 68,61. Hasil komparasi dengan metode Scheffe diperoleh kesimpulan bahwa hasil belajar matematika siswa yang memiliki motivasi belajar tinggi lebih baik daripada hasil belajar matematika siswa yang memiliki motivasi belajar rendah.

3. $\mathrm{H}_{0}: \mu_{2}=\mu_{3}$ diterima.

Rerata marginal untuk hasil belajar matematika pada siswa yang memiliki motivasi tinggi sedang adalah 73,73 sedangkan hasil belajar matematika pada siswa yang memiliki motivasi rendah adalah 68,61. Secara bilangan, kedua rerata marginal berbeda. Namun, berdasarkan hasil komparasi dengan metode Scheffe disimpulkan bahwa tidak terdapat perbedaan hasil belajar antara siswa yang memiliki motivasi belajar metematika sedang dengan siswa yang memiliki motivasi belajar matematika rendah.

\section{Pembahasan}

\section{Hipotesis Pertama}

Kelas eksperimen-1 pada penelitian ini adalah kelas X Akutansi 2 SMKN 2 Batam dengan menggunakan model pembelajaran Active Learning. Kelas eksperimen-2 pada penelitian ini adalah kelas X Akutansi 4 SMKN 2 Batam dengan menggunakan model pembelajaran ARCS (Attention, Relevance, Confidence dan Satisfaction).

Attention merupakan cara untuk mengupayakan perhatian siswa dan mempertahankan perhatian tersebut selama proses pembelajaran. Relevance merupakan keterkaitan materi terhadap kehidupan siswa. Siswa akan terdorong mempelajari sesuatu jika apa yang dipelajari ada relevansinya dengan kehidupan mereka. Confidence adalah bagaimana menumbuhkan rasa yakin pada diri siswa, dengan adanya sikap percaya diri maka akan memberi dorongan kepada siswa untuk bertindak tanpa ragu dan bersifat optimis. Satisfaction merupakan aspek yang membangkitkan rasa puas siswa terhadap pembelajaran. Kepuasan yang dimaksud adalah apabila siswa berhasil mengerjakan atau mencapai sesuatu kemudian merasa bangga atas keberhasilan tersebut atau keadaan dimana siswa merasa senang belajar dengan keadaan tertentu. Model pembelajaran Active Learning adalah model pembelajaran yang memberdayakan peserta didik agar belajar dengan menggunakan berbagai cara/strategi secara 
aktif (Silberman, 2013). Dengan diterapkannya model pembelajaraan ini diharapkan dapat meningkatkan keaktifan dan minat siswa untuk belajar.

Kedua kelas eksperimen pada penelitian ini tentunya memiliki perbedaan baik dari segi karakter siswa, jumlah siswa, motivasi belajar serta penerapan model pembelajaran yang berbeda, tentunya hasil belajar kedua kelas ini tidak sama. Namun kenyataannya, hasil belajar matematika antara siswa yang diterapkan oleh model pembelajaran ARCS dan Active Learning memberikan hasil belajar yang tidak jauh berbeda. Peneliti berasumsi bahwa faktor yang menyebabkan tidak terdapatnya perbedaan hasil belajar dari kedua kelas eksperimen adalah metode pembelajaran yang diterapkan adalah sama yakni metode belajar kelompok. Perolehan rata-rata hasil belajar matematika untuk kelas yang diberikan perlakuan model pembelajaran ARCS sebesar 74,77 dan kelas yang menerapkan model pembelajaran Active Learning sebesar 74,38. Berdasarkan rata-rata hasil belajar matematika tersebut, disimpulkan bahwa hasil belajar matematika siswa yang mengunakan model pembelajaran ARCS dan Active Learning tidak jauh berbeda, dan hasil uji hipotesis pertama pada penelitian ini dengan mengunakan anava dua jalur dengan sel tak sama diperoleh bahwa hasil belajar matematika siswa untuk kedua kelas eksperimen sama besar atau tidak ada perbedaan.

\section{Hipotesis Kedua}

Hasil analisis hipotesis kedua pada penelitian ini menyatakan bahwa terdapat perbedaan antara hasil belajar matematika siswa yang memiliki motivasi tinggi, sedang dan rendah. Namun untuk mengetahui antara motivasi belajar matematika yang mana, yang menunjukkan perbedaan maka dilakukan komparasi antara sel khususnya antar kolom (antar motivasi tinggi, sedang dan rendah) dengan menggunakan metode Scheffe. Adapun hasil komparasi tersebut adalah:

1. Tidak terdapat perbedaan antara hasil belajar matematika siswa yang memiliki motivasi belajar tinggi dengan siswa yang memiliki motivasi belajar sedang.

2. Terdapat perbedaan antara hasil belajar matematika siswa yang memiliki motivasi belajar tinggi dengan siswa yang memiliki motivasi belajar rendah.

3. Tidak terdapat perbedaan antara hasil belajar matematika siswa yang memiliki motivasi belajar sedang dengan siswa yang memiliki motivasi belajar rendah.

Motivasi merupakan penggerak, pengarah, dan pendorong timbulnya tingkah laku atau perbuatan (Hamalik, 2014). Dalam melaksanakan proses pembelajaran, motivasi menjadi salah satu unsur tercapainya tujuan pembelajaran. Setiap siswa memiliki motivasi yang berbeda-beda dalam belajar, perbedaan ini dapat dilihat dari keaktifan dan antusias siswa dalam belajar serta dari hasil belajar mereka. Belajar yang melibatkan motivasi akan menimbulkan suatu perilaku atau sikap yang semangat, antusian, aktif, dan kreatif. Semakin tinggi motivasi, antusias dan minat siswa dalam belajar maka akan semakin aktif dan kreatif siswa tersebut sehingga hasil belajar pun menjadi optimal.

\section{Hipotesis Ketiga}

Hipotesis ketiga pada penelitian ini bertujuan untuk mengetahui interaksi antara variabel bebas yakni model pembelajaran (ARCS dan Active Learning) dan motivasi belajar matematika siswa (motivasi tinggi, sedang dan rendah). Berdasarkan hasil analisis variansi dua jalan dengan sel tak sama diperoleh $\mathrm{F}_{\mathrm{obs}}=0,32$ dan $\mathrm{F}_{\mathrm{tab}}=3,09$ dengan demikian $\mathrm{H}_{0}=$ 
diterima. Artinya tidak terdapat interaksi antar model pembelajaran dan motivasi belajar siswa terhadap hasil belajar matematika siswa.

Berdasarkan hasil hipotesis pertama, diperoleh kesimpulan bahwa hasil belajar matematika siswa antara model ARCS dan Active Learning untuk masing-masing motivasi belajar matematika siswa tidak terdapat perbedaaan (ARCS: motivasi tinggi > motivasi sedang > motivasi rendah sedangkan AL: motivasi tinggi > motivasi sedang > motivasi rendah). Sedangkan berdasarkan rerata marginal antar kolom terlihat bahwa hasil belajar siswa yang memiliki motivasi tinggi tidak terdapat perbedaan yang signifikan dengan hasil belajar siswa yang memiliki motivasi sedang, begitupun pada hasil belajar siswa yang memiliki motivasi sedang, tidak terdapat perbedaan secara signifikan terhadap hasil belajar siswa yang memiliki motivasi rendah. Namun perbedaan hasil belajar terlihat antara hasil belajar siswa yang memiliki motivasi tinggi dengan hasil belajar yang memiliki motivasi rendah. Dari kesimpulan ini, maka interaksi antar model pembelajaran dan motivasi belajar matematika tidak ada. Karena tidak adanya interaksi maka uji lanjut pasca anava antar sel tidak dilakukan. Kesimpulan perbandingan rerata antar sel mengacu kepada kesimpulan perbandingan rerata marginalnya.

\section{Kesimpulan}

Berdasarkan hasil analisis data dan pembahasan penelitian dapat disimpulkan sebagai berikut.

1. Tidak terdapat perbedaan hasil belajar metematika siswa antara model pembelajaran ARCS dan Active Learning.

2. Terdapat perbedaan hasil belajar matematika antara siswa yang memiliki motivasi belajar tinggi, motivasi belajar sedang dan motivasi belajar rendah. Perbedaan ini khususnya terlihat pada hasil belajar matematika siswa yang memiliki motivasi tinggi dengan hasil belajar siswa yang memiliki motivasi rendah.

3. Tidak terdapat interaksi antara model pembelajaran (ARCS dan Active Learning) dengan motivasi belajar siswa. Hasil belajar matematika siswa antara ARCS dan Active Learning untuk masing-masing motivasi belajar siswa tidak ada perbedaan yang signifikan. Sedangkan hasil belajar matematika siswa yang ditinjau dari motivasi belajar tinggi, sedang dan rendah untuk masing-masing model pembelajaran tidak memiliki karekteristik/pola yang berbeda., sehingga hasil belajar matematika baik ditinjau dari model pembelajaran maupun ditinjau dari motivasi belajar siswa, menunjukkan bahwa tidak adanya interaksi antara model pembelajaran dan motivasi belajar siswa.

\section{Daftar Pustaka}

Farida, Anisatul. (2016). Penerapan Model Pembelajaran ARCS (Attention, Relevance, Confidence, Satisfaction) pada Mata Kuliah Matematika Diskrit Di Program Studi Teknik Informatika STMIK Duta Bangsa. Jurnal Universitas Politeknik Indonusa Surakarta. Diambil pada tanggal 28 Oktober 2016, dari

http://www.poltekindonusa.ac.id/wp-content/uploads/2016/05/Vol-1-5-2015PENERAPAN-MODEL-PEMBELAJARAN-ARCS-Anisatul Farida.pdf 
Ginting, A. (2010). Esensi Praktis Belajar dan Pembelajaran. Bandung: Humaniora.

Hamalik, Oemar. (2014). Kurikulum dan Pembelajaran Edisi.1, Cetakan 14. Jakarta: Bumi Aksara.

Silberman, M.L. (2013). Active Learning 101 Cara Belajar Siswa Aktif Edisi Revisi. Bandung: Nuansa Cendekia.

Widoyoko, Eko Putro. (2012). Teknik Penyususnan Instrumen Penelitian. Yogyakarta: Pustaka Belajar.

Zulfira, I. (2014). Penerapan Model Pembelajaran ARCS Untuk Meningkatkan Hasil Belajar Siswa Kelas VII SMP Labschool Universitas Tadulako pada Materi Sudut-sudut Segitiga. Jurnal Elektronik Pendidikan matematika, Volume 01. Diambil pada tanggal 01 November 2016

dari http://jurnal.untad.ac.id/jurnal/index.php/JEPMT/article/view/3221/2276 